\title{
Blood group, secretor status, and susceptibility to infection by Neisseria gonorrhoeae
}

\author{
D F KINANE, C C BLACKWELL, F P WINSTANLEY, AND D M WEIR \\ From the Department of Bacteriology, University of Edinburgh Medical School, Edinburgh
}

SUMMARY To determine whether the presence or absence of anti-B isohaemagglutinin in $\stackrel{\vec{\omega}}{\circ}$ individuals of blood group B increases their susceptibility to gonococcal infections 567 new patients $\stackrel{\text { ? }}{=}$. attending a sexually transmitted disease clinic were screened for blood group and secretor status. Of $\mathcal{O}_{0}$ the patients with blood group B, 20.1\% had gonorrhoea and $12 \%$ had not. A higher percentage $(20 \cdot 9 \%)$ of patients with no anti-B isohaemagglutinin had gonorrhoea compared with those without $\vec{A}$ $(12 \cdot 1 \%)$. There was, however, no synergy between the absence of anti-B isohaemagglutin and non- 윽 secretion of water-soluble blood group B antigen. Further research is needed to determine the underlying host-parasite interactions responsible for the increased susceptibility to gonorrhoea in these individuals.

\section{Introduction}

Over the past six years there have been reports of increased susceptibility of individuals of blood group B to infection with Neisseria gonorrhoeae. ${ }^{2}$ Foster and Labrum ${ }^{1}$ suggested that the presence or absence of anti-B isohaemagglutinin may be the causal factor for the reported increase in susceptibility to gonorrhoea of individuals with blood group B. In a recent study we found that individuals of blood groups $B$ and $A B-$ that is, those with no anti-B isohaemagglutinin - who were also non-secretors of blood group antigen were significantly more susceptible to urinary tract infection. ${ }^{3}$ To determine whether there is a synergistic effect between those two host factors and susceptibility to gonococcal infection we screened patients attending a department of genitourinary medicine for blood group and secretor status, and we related the data to the occurrence of gonorrhoea in these patients.

\section{Patients and methods}

During a three-month period all new patients attending the department of genitourinary medicine at the Royal Infirmary, Edinburgh, were asked to provide a specimen of blood and saliva for determination of blood group and secretor status.

Address for reprints: Dr D F Kinane, Department of Bacteriology, University of Edinburgh Medical School, Teviot Place, Edinburgh EH8 9AG

Accepted for publication 29 August 1982
Control data for blood group frequency were $\vec{\varphi}$ available for 6662 donors from the same geographical $\stackrel{\infty}{\omega}$ area. ${ }^{4}$ Secretor status control data were produced by testing 334 plasma specimens from blood donors in the survey area.

\section{SCREENING PROCEDURES}

Blood from each patient was collected at the clinic and stored in heparinised tubes. The saliva from each patient was boiled for 20 minutes, centrifuged at $500 \times g$ for 10 minutes and the supernate stored briefly at $4^{\circ} \mathrm{C}$ until tested for the presence of blood group antigen.

Blood group was determined by agglutination tests in plastic wells (WHO plates). Secretor status was determined as described by Mollinson ${ }^{5}$ with saliva or plasma samples. Samples of saliva or plasma from 윽 secretors and non-secretors representative of the four $D$ blood groups were used as controls for each experiment. Agglutinins used were anti-A and anti-B sera N and Ulex europaeus lectin. The red blood cells used were of groups $\mathrm{A}_{2}, \mathrm{~B}$, and $\mathrm{O}$. The Blood Transfusion $\stackrel{N}{\circ}$ Service, Royal Infirmary, Edinburgh, kindly supplied $\underset{\omega}{N}$ the reagents for blood grouping and determination of $\sigma$ secretor status and also performed randomo verification tests on 50 selected saliva samples and $46 \stackrel{\varnothing}{\varnothing}$ plasma samples.

\section{Results}

The distribution of blood groups of patients with and $\stackrel{\mathbb{Q}}{\mathbb{Q}}$ without gonorrhoea and of the controls is given in 
TABLE I Distribution of ABO blood groups in 567 patients with and without gonorrhoea and controls

\begin{tabular}{lcccc}
\hline & \multicolumn{2}{c}{ Culture results for N gonorrhoeae } & & \\
\cline { 2 - 4 } Blood group & No $(\%)$ negative & No $(\%)$ positive & Total No (\%) of patients & No $(\%)$ of controls ${ }^{4}$ \\
\hline O & $247(50 \cdot 3)$ & $35(46 \cdot 1)$ & $282(49 \cdot 7)$ & $3323(49 \cdot 9)$ \\
A & $176(35 \cdot 8)$ & $23(30 \cdot 3)$ & $199(35 \cdot 1)$ & $2410(36 \cdot 2)$ \\
B & $59(12 \cdot 0)$ & $16(21 \cdot 1)$ & $75(13 \cdot 2)$ & $715(10 \cdot 7)$ \\
AB & $9(1 \cdot 8)$ & $11(1 \cdot 9)$ & $214(3 \cdot 2)$ \\
Total & $491(99 \cdot 9)$ & $76(100 \cdot 1)$ & $567(99 \cdot 9)$ & $6662(100 \cdot 0)$ \\
\hline
\end{tabular}

table I. The blood group frequencies of the controls and the total number of patients attending the clinic showed no significant differences $\left(\chi^{2}=5 \cdot 864\right.$, $p>0 \cdot 1)$. The frequency of blood group $B$ in these patients with gonorrhoea was $21 \cdot 1 \%$ compared with $12 \%$ in those without. This difference was not, however, significant $\left(\chi^{2}=5 \cdot 103, p>0 \cdot 1\right)$. When the frequency of blood group $B$ in the patients with gonorrhoea was compared $(21 \cdot 1 \%)$ with that of the controls $(10 \cdot 7 \%)$ the difference $\left(\chi^{2}=8 \cdot 404\right.$, $\mathrm{p}<0 \cdot 05$ ) was significant.

The effect of the presence or absence of anti-B on susceptibility to gonorrhoea is shown in table II. A higher percentage $(20.9 \%)$ of patients with no anti-B isohaemagglutinin had gonorrhoea compared with those with anti-B isohaemagglutinin $(12 \cdot 1 \%)$ $\left(\chi^{2}=4.947, p<0.05\right)$. Using the relative risk method of Woolf ${ }^{\gamma}$ we found that the relative risk of gonorrhoea was 1.93 for individuals without anti-B isohaemagglutinin. This means that they are $93 \%$ more susceptible to gonorrhoea than persons with anti-B isohaemagglutinin.

The distribution of secretor status for patients with and without gonorrhoea and controls is given in table III. No significant differences were noted between the total patients and the controls $\left(\chi^{2}=0.917, p>0 \cdot 1\right)$ nor between those patients with and without gonorrhoea $\left(\chi^{2}=0 \cdot 168, \mathrm{p}>0 \cdot 5\right)$.

TABLE II Analysis of data from table I by presence or absence of anti-B isohaemagglutinin

\begin{tabular}{|c|c|c|c|}
\hline \multirow[b]{2}{*}{$A n t i-B$} & \multicolumn{2}{|c|}{$\begin{array}{l}\text { Culture results for } \\
\text { N gonorrhoeae }\end{array}$} & \multirow[b]{2}{*}{ Total } \\
\hline & $\begin{array}{l}\text { No }(\%) \\
\text { negative }\end{array}$ & $\begin{array}{l}\text { No (\%) } \\
\text { positive }\end{array}$ & \\
\hline $\begin{array}{l}\text { Present }(\mathrm{O} \text { and } \mathrm{A}) \\
\text { Absent (B and } \mathrm{AB}) \\
\text { Total }\end{array}$ & $\begin{array}{l}423(87 \cdot 9) \\
68(79 \cdot 1) \\
491\end{array}$ & $\begin{array}{l}58(12 \cdot 1) \\
18(20 \cdot 9) \\
76\end{array}$ & $\begin{array}{l}481(100) \\
86(100) \\
567\end{array}$ \\
\hline
\end{tabular}

\section{Discussion}

Our findings confirm those of others ${ }^{12}$ that individuals of blood group B are more susceptible to gonococcal infection and further suggest that the absence of anti-B isohaemagglutinin is important.

An increase in the number of non-secretors among patients with gonococcal infections had been predicted, but this was not observed. Although there was a significant increase in the number of blood group $B$ individuals among the infected patients, there was no synergy between the absence of anti-B isohaemagglutinin and non-secretion of water soluble blood group B antigen comparable to that found in patients with urinary tract infections. ${ }^{3}$

The underlying host-parasite interactions responsible for the increased susceptibility of individuals with no anti-B isohaemagglutinin to gonococcal infection are not yet known; they appear, however, to differ from those involved with other Gram-negative, urinary tract pathogens. Accordingly, we are currently investigating the role of anti-B isohaemagglutinin in normal human serum acting as an opsonin or as bactericidal antibody, gonococcal interactions with human phagocytic cells of the different blood groups, and differences in the attachment of gonococcal strains to epithelial cells from individuals with different $\mathrm{ABO}$ blood groups.

We are most grateful to Dr D H H Robertson and his colleagues in the department of genitourinary medicine, Royal Infirmary, Edinburgh, for their assistance in the collection of blood and saliva specimens, to Dr H Young for the results of bacteriological investigations, and to $\mathrm{Dr} \mathrm{R} A$ Elton for assistance with the statistical analysis of our data. We also thank Professor J G Collee for his advice in

TABLE III Distribution of secretor status for patients with and without gonorrhoea and controls

\begin{tabular}{|c|c|c|c|c|}
\hline \multirow[b]{2}{*}{ Secretor status } & \multicolumn{2}{|c|}{ Culture results for $N$ gonorrhoeae } & \multirow[b]{2}{*}{ Total No $(\%)$ of patients } & \multirow[b]{2}{*}{ No $(\%)$ of controls } \\
\hline & No (\%) negative & No (\%) positive & & \\
\hline $\begin{array}{l}\text { Secretor } \\
\text { Non-secretor } \\
\text { Total }\end{array}$ & $\begin{array}{l}344(70 \cdot 1) \\
147(29 \cdot 9) \\
491(100)\end{array}$ & $\begin{array}{l}55(72 \cdot 4) \\
21(27 \cdot 6) \\
76(100)\end{array}$ & $\begin{array}{l}399(70 \cdot 4) \\
168(29 \cdot 6) \\
567(100)\end{array}$ & $\begin{array}{c}245(73 \cdot 4) \\
89(26 \cdot 6) \\
334(100)\end{array}$ \\
\hline
\end{tabular}


preparation of the manuscript and Mrs M Cole for its typing. This investigation was supported by grant K/MRS/50/C22 from the Biomedical Research Committee, Scottish Home and Health Department, and by grants $\mathrm{G} 81 / 103811 / \mathrm{SB}$ and $\mathrm{G} 979 / 64 / \mathrm{S}$ from the Medical Research Council.

\section{References}

1. Foster MT, Labrum AH. Relation of infection with Neisseria gonorrhoeae to ABO blood groups. J Infect Dis 1976; 133:329.
2. Miler JJ, Novotny $\mathbf{P}$, Walker PHD, Harris JRW, MacLennan IPB. Neisseria gonorrhoeae and ABO isohaemagglutinins. Infect Immun 1977;15:713.

3. Kinane DF, Blackwell CC, Brettle RP, Weir DM, Winstanley FP, Elton RA. ABO blood groups, secretory state, and susceptibility $\overline{\bar{n}}$ to recurrent urinary tract infection in women. $\mathrm{Br}$ Med J 1982;285:7.

4. Kopec AC. The Distribution of the Blood Groups in the United Kingdom. London, New York, Toronto: Oxford University Press, 1970;26.

5. Mollinson PL. Blood Transfusion in Clinical Medicine. 6th ed. Oxford: Blackwell, 1979;414.

6. Woolf $B$. On estimating the relation between blood group and disease. Ann Hum Genet 1954/55;19:251. 